\title{
Developing Batik Learning Model in Early Childhood: Video Learning and Guide Book
}

\author{
Adharina Dian Pertiwi, Panggung Sutapa \\ Yogyakarta State University, Yogyakarta, Indonesia \\ e-mail: adharina.dian2016@student.uny.ac.id
}

\begin{abstract}
Batik learning model is important to support learning and culture process. It helps teacher and children to know batik process from first to end using plastic canting and malam dingin liquid. This study aimed to find out what media is needed and how it gave significant progress in batik learning process. This type of research is the Research and Development ( $\mathrm{R} \& \mathrm{D})$. This developmental research adapted the model of Borg \& Gall which was simplified to 7 development stages and it's divided into three main parts: (1) Preliminary study, (2) Product Development Stage, and (3) Product Testing Stage. The subjects for small scale test were 10 children, 30 children for field tests, and 42 children for effectiveness tests. Data were collected using interview, observation sheet, and validation sheet. Data analysis technique for the effectiveness test was Paired Sample Test with significance 0.05 . The research of the research was a model of batik learning in the form of a video learning and a guide book that consisted of learning steps of the batik namely an introduction, main activities, and evaluation. The main activities were batik techniques namely nyungging, njaplak, nglowong, ngiseni, nyolet, ngelir, mopok, and nglorod. Experts and practitioners validation result could be concluded that the developed model was in the category "very good". The result was effective because of t-test was sig (p) $<0.05$ which meant that there was a significant change between the ability of the children before and after being treated.
\end{abstract}

Keywords: $\quad$ learning model, batik, early childhood

\section{INTRODUCTION}

Vygotsky states that culture and social environment of a child is the most important thing that influences their knowledge formation. Children learn through song, art, and games. Culture influences children learning process because children learn through interaction and contribution with the surroundings. Interaction of interpersonal factors (social), cultural-historical, and individual as the key of human development (Schunk, 2012).

Batik is an Indonesian culture heritage that children need to learn from an early age. Batik learning in Pekalongan, Central Java has now become a mandatory teaching and learning activity as it is contained in the local content. However, the process of learning batik is complicated and associated with risky hot malam for children seems to be teachers constraint to teach batik learning process to children. Based on that many people think that batik activities can't be done to early childhood, but in fact, batik activities can be done to children with assistance and tools and materials that are safe for children. Therefore, safety batik learning model is very necessary as a guide to implementation of batik from an early childhood

Brewer (2007) states that early childhood learning models defined to plan and set children experiences. Learning model used as a guideline for learning designers so that learning reach a goal with systematically structured. Joyce and Weil (1992:4) state that learning model is a plan or pattern used to create a learning plan, teaching materials, and guides learning in the classroom. The student's increased 
capabilities to learn to more easily and effectively in the future.

Johnston (2010) states that to know the quality of applied learning model can be seen from two aspects are process and product. Process aspect is learning to create fun learning situation and encourage chldren to be active and creative thinking, while product aspect leads to children's ability to achieving the goals through improving the ability or competence desired. The product in batik learning model is learning media.

Heinich (1996) states that media is a communication channel, derived from a Latin word meaning "between" this word refers to something that carries information between the message sender to the recipient of the message. The functions of media are generated learning motivation, repeat what has been learned, to provide a learning stimulus, activated student response, provide quick feedback/ prompt and promote suitable exercise (Rowntree, 1982). Learning media in batik learning model are video learning and guide book.

Video learning aimed to guide the process of batik learning that can seen by children and teacher as audio-visual media. Guide book is used for teacher-readable instructions before doing and watching the video learning and doing the batik learning process. Video learning and guide book as a digital media so that the process of batik learning directed according to its stages.

\section{METHOD}

This type of research is the Research and Development aimed to develop product of batik learning model in form of video learning and guide book. The basic aims of education research were not only to develop product, but also to discover the knowledge (through basic research) or to answer specific question about practical problems (through applied research) (Borg and Gall, 1983: 772). Educational research and development ( $R$ and $D)$ is a process used to develop and validate educational products.

Educational R \& D nowadays, become famous along with the need of educational to develop products in enhancing the educational quality although more difficult and consuming time. The product refers to not only material subjects, such as textbook, instructional films, and so forth, but also refers to the constructed procedures and the processes such as the material of teaching or method for organizing instruction.

The measures used in this study using seven main steps, namely: 1 . Conduct preliminary research and collection of information, including field observation and study of literature, 2. Develop an initial product form the batik learning model, 3 . Evaluation of the experts by using two experts, as well as small scale trial using a validation sheet and consultation and subsequent evaluation of the results were analyzed in depth, 4. Revision of the first product, a revision of products based on the results of the expert evaluation and small-scale trials. This revision is used for improvements to the initial product made by researchers, 5. The large-scale trials using learning model development that has been revised on the results of small scale trials carried out previously, 6 . Results of the final product which is based on large-scale testing, 7. The final result of the development of batik learning model generated through the revision of large-scale trial.

The final product used for effectiveness test. The aim of effectiveness test is to know the effectiveness level of developed product in development batik learning model. Observation sheet use to observe the effectiveness test. From the observation results obtained changes before and after treatment in batik learning model implementation. Product effectiveness test using pre-experimental design research method one-group pretest-posttest design periodically to show maximum learning output.

The subject is children in kindergarten group B. Subjects for small-scale test were 10 children, 30 children for large-scale test, and 42 children for effectiveness test.

Analysis of quantitative descriptive validation results using Likert scale formula. The score of validation result then conserved intervals with very good (5), good (4), enough (3), less (2), and not good (1). In this research, feasibility value of the product determined that at least " $\mathrm{B}$ " is in the Good category so the developed model has been considered feasible if the result of overall final assessment from expert validator team gets the minimum grade "Good".

Observation results analysis consists of one to four assessment ranges with each assessment already have the assessment rubric. After obtaining the average score, the prerequisite test (normality test and homogeneity test) and t-test were done. T-test results used to find out the difference between the 
experimental group pre-test and post-test. The null hypothesis (Ho) and the alternative hypothesis (Ha).

$\mathrm{H}_{\mathrm{o}}$ : There was no significant difference between the children skills score before and after being treated. And the $\mathrm{H}_{\mathrm{a}}$ : there was a significant difference between the children skills score before and after being treated.

\section{RESULT AND DISCUSSION}

This research and development resulted in the batik learning model which is packaged in learning video (CD) and guide book. Batik learning model developed and declared feasible to use based on validation result from matter experts, media experts, and teachers also children progress achievement after using the media.

\section{Preliminary Study}

This stage begins with a preliminary study or needs analysis. Needs analysis has done in order to know the problems or obstacles that occur in the field. Need analysis conducted in Pekalongan by observations and interviews in four kindergartens that represent each district in Pekalongan. Based on observations and interviews result of principals and teachers it is known that:

First, Pekalongan is an icon of world city of batik that there should stimulate from an early age, but in fact, based on observation result batik learning has not been implemented in kindergarten only in the local content curriculum. Second, there are children who can win the contest "Coloring (Nyolet) Batik Buketan" in Pekalongan in order to commemorate Batik Day, but batik activities in learning, local content or extracurricular to support and improve batik learning not held in school.

Third, the knowledge of some teachers who are still holding on canting and hot malam in learning activities making batik learning in children is not safe. Fourth, the government has not given support in the form of learning manual and materials to support the preservation of batik culture in early childhood learning.

Based on that explanation, it is known that developing batik learning model need to be done. Therefore, researchers have thought to develop that batik learning. This batik learning are batik steps from first to end to stimulate child development aspect. All activities must be carried out orderly and to completion.

\section{Product Development Stage}

Developing batik learning model is generated based on needs analysis. Analysis result of batik learning model are learning steps. Batik learning model steps consist of introduction, main activity, and evaluation.

Introduction, in preliminary activities, teacher conditioned the children to lining up, entering class, and praying according to their beliefs. Main activities, consist of 8 activities of the batik process. This is supported by a statement Hestiasari Rante (2016: 581):

"In Indonesia the technique of drawing batik pattern on fabric is an ancient method. Batik craftsmen use traditional tools called canting and cap to create intricate designs. The main process generally consists of eight steps: 1) Nyungging Sketching and drawing pattern on a paper. 2) Njaplak - Moving the drawn pattern on paper to the fabric. 3) Nglowong - Waxing pattern on fabric with canting. 4) Ngiseni - Putting isen (fill) to the main pattern. 5) Nyolet - Coloring some parts of the pattern using paintbrush. 6) Mopok - Covering parts that have been colored with wax using paintbrush. 7) Ngelir - Coloring the whole fabric by putting fabric into colored water. 8) Nglorod - Removing wax by pouring fabric into boiling water".

Based on that statement, the 8 main activities in the batik process namely nyungging, njaplak, nglowong, ngiseni, nyolet, mopok, ngelir, and nglorod. These 8 activities carried out orderly and fit with child development stage and also providing safety tools and materials for learning. Evaluation, the final activity of learning in the form of evaluation.

Step by step of batik learning was packaged in a $\mathrm{CD}$ and a guide book. On the CD there is learning video which is audio-visual media used for teachers to understand the implementation process of batik learning model. Guide book used as a teacher's guide in the implementation of batik learning model.

\section{Video Learning}

Video learning was packaged in a $\mathrm{CD}$, has a function an audio-visual media for teachers and children to understand and implement batik learning model guided by a narrator. Teacher and children can see and hear directly how batik learning process so they can understand batik learning steps. Developmental video learning has a structural 
component and video format, video display, video design, and the language used.

Structure and format in video of batik learning consist of the name of the researcher and educational institution, development title, explanation of learning steps and activities of each batik stage by a narrator and clarified by writing. Batik learning consisted of the introduction, main activities, and evaluation. The main activities were 8 batik techniques begins with nyungging ends with nglorod.

Video display was displayed in bold and italic, the font size is adjusted to video background, the video contains video of the children activities when batik learning. Design in video batik learning looks clear and clean, backsound are musical child instruments, space and layout of the description, The language in video learning adjusted to Indonesian EYD, polite, simple, clear, and easy.

\section{Guide Book}

Guide book is a guide book for teachers to understand the batik learning model. Guide book qualities consisted of structure and format, display, design, and language.

Structure and writing format of the guide book contains title, preface, table of contents, introduction, general purpose, special purpose, facilities and infrastructure, technical guidance, implementation batik activities, indicator of success. Writing technique such as capital letters, the topic was written in bold, an appropriate comparison between upper size with images, there are images of learning activity, color combinations, images, and texts in tune.

The design consists of an interesting layout, compatible page background, print clarity, the sharing of the images. Linguistic aspect consisted of use language based on Indonesian EYD, use simple sentences, clear, and easy to understand.

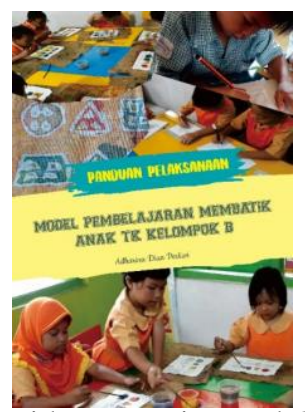

Fig. 1. Cover Video Learning and Guide Book Batik Learning Model

\section{Product Testing Stage}

Before conducting product trials of developing batik learning model, it first has to be validated by matter experts and media experts to find out the product feasibility. Matter expert in this research is Dr. Harun, M.Pd., while the media expert Dr. Sujarwo, M.Pd. Matter expert validates assessment instrument (observation) and matter content component, while media expert validate the instrument feasibility of product design from video learning media (compact disc) and guide book.

Experts advise the developed product feasibility by validating the product. Expert validation results (both validation sheet or suggestions or comments) will be the basic to revise the developed product. Validation was done by providing validation sheet to the matter experts and media experts. The number of ratings given by the validator experts will then be analyzed by conserving to Likert scale.

Table 1. Results of Validation Expert Matter and Media

\begin{tabular}{|c|c|c|c|c|}
\hline Name & Score & $\begin{array}{l}\text { Score } \\
\text { Min }\end{array}$ & $\begin{array}{l}\text { Score } \\
\text { Max }\end{array}$ & Category \\
\hline Dr. Harun, M.Pd & 80 & 20 & 100 & Good \\
\hline Dr. Sujarwo, M.Pd & 127 & 30 & 150 & $\begin{array}{l}\text { Very } \\
\text { Good }\end{array}$ \\
\hline
\end{tabular}

Based on validation result in the table, it can be concluded that the developed product declared "feasible" to use. The assessment is obtained after the researcher revised the product according to validator expert suggestions and comments so resulting product which is feasible to use.

1. Small-Scale Test

After the initial validation of the developed product till fit for use, so small-scale test is done. Small-scale test were conducted on 10 children with the average total value 2,8 . Practitioners validation results in small-scale test got a total score of 96 with "very good" category. The suggestion is scheduling in batik learning so the teacher can give the children maximum time in completing each activity in batik learning.

2. Field Test or Large-Scale Testing

The field test subjects were 30 children consists of two kindergartens. There is an increase in the child ability from the previous average score of 3,2. Practitioners validation results is not much different with score in small-scale test so it is worth to use with a category "very good". 


\section{Effectiveness Test}

The effectiveness test subjects were 42 children consists of two kindergartens. Effectiveness test aimed to find out product effectivity of batik learning model. Data from effectiveness test include observation data of learning implementation to measure the children ability in batik learning. In the implementation process and observation process researchers involving one friend as an observer.

The effectiveness test conducted six times treatment within six weeks with twice a week. In one week includes four days because it's divided in two kindergartens. Before starting the learning teachers and children watched video learning and teacher learn guide book of batik learning model.

At the beginning of batik learning, a pre-test for the child is aimed to determine the level of initial ability. After pre-test, teacher give more treatment in batik learning model implementation using the developmental product are video learning and guide book for many times till reached the children maximum score.

At the $6^{\text {th }}$ meeting, children have reached the maximum score due to an increase slightly even almost the same from the $5^{\text {th }}$ meeting, so the researcher took post-test data at $6^{\text {th }}$ treatment assessed by the observer. A post-test aimed to find out the effectivity use of the developmental product in batik learning process.

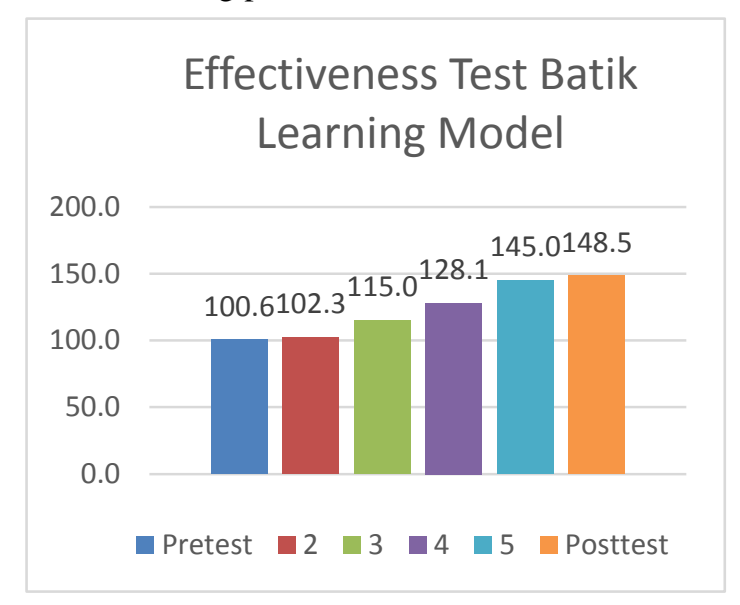

Fig. 2. Effectiveness Test Batik Learning Model

Based on the statistical analysis results of pretest and post-test then took a prerequisite test (normality and homogeneity test), and t-test using the anaylisis of Independent Sample Test. a) Normality test

Table 2. Normality Test Pretest and Posttest

\begin{tabular}{|c|c|c|c|}
\hline & & pretest & posttest \\
\hline \multicolumn{2}{|c|}{$\mathrm{N}$} & 42 & 42 \\
\hline \multirow{2}{*}{$\begin{array}{c}\text { Normal } \\
\text { Parameters }^{a, b}\end{array}$} & Mean & 2,402 & 3,552 \\
\hline & $\begin{array}{c}\text { Std. } \\
\text { Deviation }\end{array}$ & , 4836 &, 2856 \\
\hline \multirow{3}{*}{$\begin{array}{l}\text { Most Extreme } \\
\text { Differences }\end{array}$} & Absolute & 130 &, 188 \\
\hline & Positive &, 115 & 112 \\
\hline & Negative &,- 130 &,- 188 \\
\hline \multicolumn{2}{|c|}{ Kolmogorov-Smimov Z } & 841 & 1,218 \\
\hline \multicolumn{2}{|c|}{ Asymp. Sig. (2-tailed) } & ,479 & 103 \\
\hline \multicolumn{2}{|c|}{ Point Probability } &, 000 &, 000 \\
\hline
\end{tabular}

Normality test result using the KolmogorovSmirnov pre-test results the value of $\mathrm{Z}$ obtained 0,841 with significance (sig.) 0,479 , as the significance value $0,479>0,05$ then the pre-test data were normally distributed. And normality test result using the Kolmogorov-Smirnov post-test result the value of $\mathrm{Z}$ obtained 1,218 with significance (sig.) 0,103 , as the significance value $0,103>0,05$ so posttest data were normally distributed.

b) Homogeneity Test

Table 3. Homogeneity Test

Test of Homogeneity of Variances

\begin{tabular}{|c|c|c|c|}
\hline $\begin{array}{c}\text { Levene } \\
\text { Statistic }\end{array}$ & df1 & df2 & Sig. \\
\hline 2,813 & 6 & 33 &, 125 \\
\hline
\end{tabular}

Homogeneity test results from pre-test and post-test data the calculated $\mathrm{F}$ value obtained 2,813 with significance 0,125 . Because the significance amount $0,125>0,05$ so pre-test and post-test data were homogeneous. 
c) T-test

Table 4. T-test

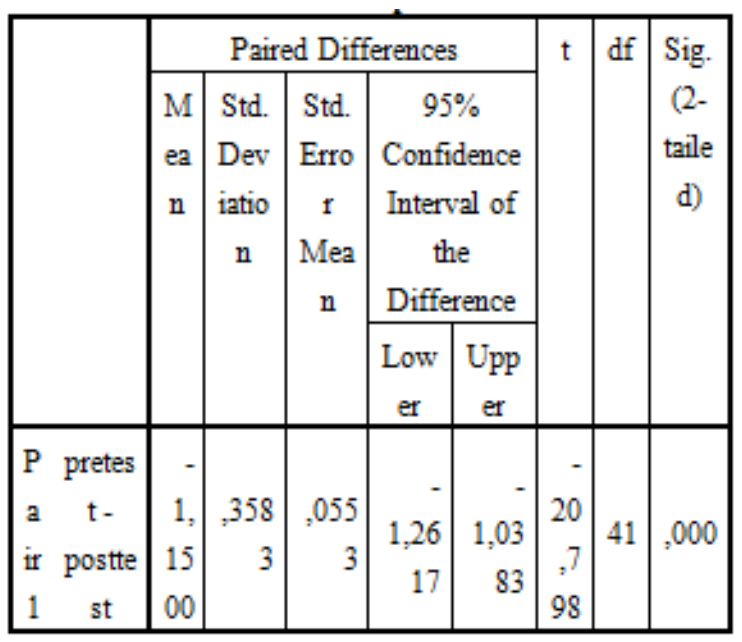

Difference test results of two mean between pre-test and post-test data the $\mathrm{t}$ count obtained 20,798 with significance 0,000 because significance value $0,000<0,05$ so can be concluded that there was a difference between pre-test and post-test result. Post-test result better than the pre-test result. So it can be concluded that $\mathrm{Ho}$ is rejected and $\mathrm{Ha}$ accepted.

\section{CONCLUSION}

Batik is a cultural heritage that needs to introduce from an early childhood. A safety batik learning model for children is urgently needed. Video learning and guide book were research product developing batik learning model for an early childhood. Video learning was packaged in CD that can be watched through digital media such as TV or laptop, which has function as a visual-audio media for teachers and children to understanding and implementing batik learning model guided by a narrator. Guidebook use for teachers to understand the implementation of batik learning model.

Batik learning model steps consist of introduction, main activities, and evaluation. The Introduction step consists of marching activity, praying, and introduction activities. Then, the main activities consist of activities namely nyungging, njaplak, nglowong, ngiseni, ngelir, mopok, and nglorod. The evaluation consist of learning evaluation activities, praying, and greeting. Batik learning model requires a minimal learning time for two days with coherently activities, but if carried out over two days it would be maximizing the results and learning preparation.

The main activities in batik learning consisted of eight activities, namely (1) nyungging or draw a pattern with a bold contact point, (2) njaplak or imitating (menjaplak) pattern, (3) nglowong or paint the image patterns on fabric using plastic canting, (4) ngiseni or paint motifs in patterns using canting, (5) nyolet or coloring every pattern with brush, (6) mopok or covering the colored patterns with cold malam liquid using a brush, (7) ngelir or dipping and lifting fabric in colored water, and (8) nglorod or dipped the fabric in a shed (pelorod) malam liquid by poking around. Tools and materials that required in batik learning model activities were as follows: (1) markers and paperboard, drawing paper geometry pattern, (2) pencils, drawing paper, staplers, fabric size A4 and paperboard, (3) fabric drawing, plastic canting, cold malam liquids, and paperboard, (6) fabric drawing, brush, cold malam liquid, plastic glasses, and gunny sack, (7) fabric drawing, hand gloves, dye liquid, buckets, and raffia strings, and (8) fabric drawing, buckets, sticks, shed malam liquid.

Validation results from experts and practitioners could be concluded that the developed model was in a category "very good" and "very decent" to used in learning process. And children's overall learning output has increased in children post-test score from initial skills or pre-test score. Output Paired Sample t Test shows that the value sig (2-tailed) which is 0,000 less than 0,05. So, it can be concluded that $\mathrm{Ho}$ is rejected and $\mathrm{Ha}$ accepted. There was a significant difference between pre-test and post-test result or there was a difference before and after treatment, so batik learning model using plastic canting and cold malam liquid was effective and appropriate for early childhood.

Suggestion for utilization of this developed model can be adopted by schools that want to apply batik learning as local content or extracurricular activities. Developed product as batik learning model can be further expanded by different image patterns or accordance with the theme of early childhood. As well as developed product could be further developed by discover other developmental aspects. 


\section{REFERENCES}

[1] Borg and Gall (1983). Educational Research. An Introduction. New York: Longman.

[2] Brewer, J.A. (2007). Introduction To Early Childhood Education. USA: Pearson Education Inc.

[3] Heinich, R.,et al. (1996). Instructional Media And Technologies For Learning. New Jersey: Prentice Hall, Englewood Cliffs.

[4] Hestiasari Rante, Heidi Schelhowe, and Michael Lund. (2016). A Preliminary Design of BatiKids: A Game-Based Learning to Support Children Learning the Process of Producing Traditional Batik in Museum Context. International Journal of Information and Education Technology, Vol. 6, No. 7, pp 580583.

[5] Hurlock, Elizabeth B. (1978). Child development. Jakarta: Erlangga.
[6] Johnston \& Haloca. (2010). Early Childhood And Primary Education Readings And Reflections. New York: McGraw-Hill, Open University Press.

[7] Joyce, B.R., Marsha, W., \& Bevely, S. (1992). Models of teaching. London: Prentice-Hall International.

[8] Sari, Rina Pandan. (2013). Batik skills for children. Surakarta: Arcita.

[9] Rowntree, Derek. (1982). Educational Technology In Curriculum Development. London: Harper \& Row.

[10] Santrock, J. W. (2012). Child development: an ontroduction. New York: McGraw-Hill.

[11] Schunk, Dale. H. (2012). Learning Theories: An Educational Perspectives, 6th Edition. New York: Pearson Education Inc.

[12] Sleeman, Philip J \& Cobun Ted C, Rockwell. (1979). Instructional media and technology. New York: Longman , Inc 